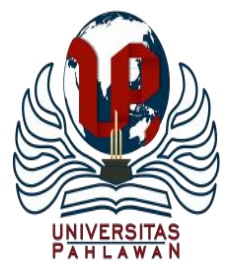

Edukatif : Jurnal Ilmu Pendidikan Volume 3 Nomor 4 Tahun 2021 Halm 1550 - 1558

EDUKATIF: JURNAL ILMU PENDIDIKAN

Research \& Learning in Education

https://edukatif.org/index.php/edukatif/index

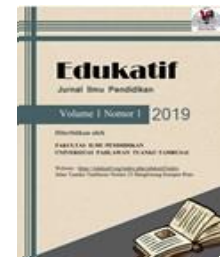

\title{
Analisis Pemahaman Guru Sekolah Menengah Pertama (SMP) Mengenai Asesmen Kompetensi Minimum (AKM)
}

\author{
Aifah Fauziah ${ }^{1 凶}$, Enur Fitriani Dewi Sobari ${ }^{2}$, Babang Robandi ${ }^{3}$ \\ Universitas Pendidikan Indonesia, Indonesia ${ }^{1,2,3}$ \\ E-mail : aifah.fauziah@upi.edu ${ }^{1}, \underline{\text { enur_fitriani17@ @upi.edu }}^{2},{\text { brobandi@ } \text { upi.edu }^{3}}^{3}$
}

\begin{abstract}
Abstrak
Penulisan artikel ini bertujuan untuk menganalisis pemahaman guru Sekolah Menengah Pertama (SMP) dalam memahami Asesmen Kompetensi Minimum (AKM). Penelitian ini menggunakan metode survei dengan jenis penelitian kuantitatif deskriptif dan Instrumen yang digunakan untuk mengumpulkan data adalah angket menggunakan google form. Tenik pengambilan sampel menggunakan teknik purposive sampling. Data yang diperoleh dianalisis menggunakan statistik deskriptif. Hasil penelitian menunjukkan ini bahwa $100 \%$ guru mengetahui apa itu asesmen kompetensi minimum, 87,5\% guru mengetahui komponen apa saja dari literasi membaca dan numerasi yang akan diukur dalam asesmen kompetensi minimum dan sebanyak $12,5 \%$ guru tidak mengetahui, $62,5 \%$ yang menyatakan tidak hanya literasi membaca dan numerasi yang diukur pada soalsoal asesmen kompetensi yang menjawab dan $37,5 \%$ ya, $25 \%$ guru menjawab untuk masing-masing soal literasi membaca dan numerasi yaitu 36 soal dan $75 \%$ yaitu 30 soal. Hasil penelitian menunjukkan asesmen kompetensi minimum perlu untuk disosialisasikan yang lebih terhadap guru.
\end{abstract}

Kata Kunci: Asesmen Kompetensi minimum (AKM), Literasi membaca, Numerasi

\begin{abstract}
This study aims to analyze the understanding of junior high school (SMP) teachers in understanding the Minimum Competency Assessment (AKM). The study method using is descriptive quantitative research type and the instrument used to collect data is a questionnaire using google form. The sampling technique using purposive sampling. The data obtained were analyzed using descriptive statistics. The result showed knowledge of $100 \%$ of teachers know what the minimum competency assessment, $87.5 \%$ of teachers know what components of reading literacy and numeracy, which will be measured in the assessment of the competence of a minimum, and as much as $12.5 \%$ of teachers who do not know, $2.5 \%$ stated that not only reading literacy and numeracy were measured on competency assessment questions who answered and 37.5\% yes, $25 \%$ of teachers responded to each about reading literacy and numeracy which is 36 questions and $75 \%$ of 30 questions. The results showed an assessment of minimum competency needs to be socialized to the teacher.
\end{abstract}

Keywords: Assessment of the Competence of the minimum (AKM), reading Literacy, Numeracy

Copyright (c) 2021 Aifah Fauzaih, Enur Fitiriani Dewi Sobari, Babang Robandi

$\triangle$ Corresponding author:

Email : aifah.fauziah@upi.edu

DOI : https://doi.org/10.31004/edukatif.v3i4.608

ISSN 2656-8063 (Media Cetak)

ISSN 2656-8071 (Media Online)

Edukatif : Jurnal Ilmu Pendidikan Vol 3 No 4 Tahun 2021 p-ISSN 2656-8063 e-ISSN 2656-8071 
1551 Analisis Pemahaman Guru Sekolah Menengah Pertama (SMP) Mengenai Asesmen Kompetensi Minimum (AKM) - Aifah Fauzaih, Enur Fitiriani Dewi Sobari, Babang Robandi

DOI: https://doi.org/10.31004/edukatif.v3i4.608

\section{PENDAHULUAN}

Salah satu upaya yang dilakukan pemerintah untuk meningkatkan kualitas pendidikan adalah menetapkan standar nasional pendidikan memuat kriteria minimal tentang komponen pendidikan yang memungkinkan setiap jenjang dan jalur pendidikan untuk mengembangkan pendidikan secara optimal sesuai dengan karakteristik dan kekhasan programnya. Seperti yang tertuang dalam PP 19 Tahun 2005 yaitu "terdapat Delapan Standar Nasional Pendidikan sebagaimana tertuang dalam Pasal 2 Ayat (1), yaitu meliputi, standar kompetensi lulusan, standar isi, standar proses, standar pendidikan dan tenaga kependidikan, standar sarana dan prasarana, standar pengelolaan, standar pembiayaan dan standar penilaian". Selain itu upaya yang dilakukan penmerintah untuk mengendalikan mutu pendidikan adalah dengan melaksanakan evaluasi (Novita et al., 2021). Dalam bidang pendidikan, evaluasi juga berarti mengukur atau mengamati proses untuk menilai dan menentukan nilainya dengan membandingkannya dengan yang lain atau dengan standar ukuran yang sudah ditetapkan (Adom et al., 2020).

Evaluasi pendidikan adalah salah satu komponen utama yang tidak terpisahkan dengan komponen pendidikan. Namun, tidak semua bentuk evaluasi dapat dipakai untuk mengukur pencapaian tujuan pendidikan yang telah ditentukan. Keberhasilan pendidikan akan dapat dilihat apabila alat ukur evaluasi yang digunakan sesuai dan dapat mengukur setiap tujuan. Diperlukan alat ukur yang relevan agar hasil pengukuran tepat. Karena jika tidak hasilnya bisa tidak tepat bahkan salah sama sekali. Evaluasi dapat dilakukan terhadap peserta didik, lembaga, dan program pendidikan pada jalur formal dan nonformal untuk semua jenjang, satuan, dan jenis pendidikan. Oleh karena itu, setiap langkah evaluasi hendaknya didasarkan pada prinsip untuk mencapai sesuatu yang lebih baik dari sebelumnya, dengan demikian, setiap evaluasi adalah upaya untuk mencapai kualitas pendidikan yang lebih baik (Ayang Sari, Syahnan Daulay, Yola Yuliani Putri, 2020).

Salah bentuk program evaluasi yang dilakukan oleh Kemendikbud yaitu dengan menghapus UN. Kementerian Pendidikan dan Kebudayaan telah memutuskan bahwa pelaksanaan Ujian Nasional (UN) akan berakhir tahun 2020. UN diganti dengan Asesmen Kompetensi Minimum (AKM) dan survei karakter yang akan diimplementasikan pada tahun 2021. Guna merealisasikan kebijakan AKM ini. Pengembangan AKM didasarkan padan kombinasi antara Programme for International Student Assessment (PISA) dengan Trends in International Mathematics and Science Study (TIMSS). Selanjutnya Kemendikbud merancang suatu prototype metode asesmen yang dinamakan AKSI atau Asesmen Kompetensi Siswa Indonesia(M. Anas, Mochamad Muchson, Sugiono, 2021). Asesmen Kompetensi Minimum (AKM) merupakan penilaian kompetensi mendasar yang diperlukan oleh semua murid untuk mampu mengembangkan kapasitas diri dan berpartisipasi positif pada masyarakat. Terdapat dua kompetensi mendasar yang diukur AKM, yaitu literasi membaca dan literasi matematika (numerasi). Baik pada literasi membaca maupun numerasi, kompetensi yang dinilai mencakup keterampilan berpikir logis-sistematis, keterampilan bernalar menggunakan konsep dan pengetahuan yang telah dipelajari, serta keterampilan memilah serta mengolah informasi. AKM menyajikan masalah-masalah dengan beragam konteks yang diharapkan mampu diselesaikan oleh murid menggunakan kompetensi literasi membaca dan numerasi yang dimilikinya. AKM dimaksudkan untuk mengukur kompetensi secara mendalam, tidak sekedar penguasaan konten (Mendikbud, 2020).

Secara umum asesmen tidak hanya menilai pengetahuan saja, tetapi mencakup semua metode yang digunakan mengumpulkan informasi tentang pengetahuan, kemampuan, pemahaman, sikap, dan motivasi (OECD, 2015). Asesmen dalam kegiatan pembelajaran merupakan elemen yang sangat penting dilakukan untuk mengumpulkan data dan informasi yang dibutuhkan terkait proses pembelajaran (Pellegrino, 2014). Sistem asesmen yang ideal dirancang secara kontinu, dilakukan lebih dari sekedar mendokumentasikan kemampuan siswa dan apa yang mampu mereka lakukan. Artinya, penilaian harus mengukur kemajuan siswa seiring waktu, untuk memberikan gambaran kemajuan seutuhnya, hasil pengamatan dari waktu ke waktu harus dihubungkan secara konseptual sehingga perubahan dapat diamati dan ditafsirkan (Baird et al., 2017). 
1552 Analisis Pemahaman Guru Sekolah Menengah Pertama (SMP) Mengenai Asesmen Kompetensi Minimum (AKM) - Aifah Fauzaih, Enur Fitiriani Dewi Sobari, Babang Robandi

DOI: https://doi.org/10.31004/edukatif.v3i4.608

Data yang diperoleh dapat digunakan untuk membuat keputusan tentang isi dan metode pengajaran, untuk membuat keputusan tentang iklim ruang kelas, dan untuk memberikan nilai (Brown, 2019). Tingkat kemajuan siswa dalam pembelajaran harus mendasari sistem asesmen, dan pengujian harus dirancang untuk memberikan informasi serta memetakan kembali perkembangan pembelajaran (Wiliam, 2011).

Asesmen dilakukan untuk mendapatkan informasi mengetahui capaian murid terhadap kompetensi yang diharapkan. Asesmen Kompetensi Minimum dirancang untuk menghasilkan informasi yang memicu perbaikan kualitas belajar-mengajar, yang pada gilirannya dapat meningkatkan hasil belajar murid. Pelaporan hasil AKM dirancang untuk memberikan informasi mengenai tingkat kompetensi murid. Tingkat kompetensi tersebut dapat dimanfaatkan guru berbagai mata pelajaran untuk menyusun strategi pembelajaran yang efektif dan berkualitas sesuai dengan tingkat capaian murid. Dengan demikian "Teaching at the right level" dapat diterapkan. Pembelajaran yang dirancang dengan memperhatikan tingkat capaian murid akan memudahkan murid menguasai konten atau kompetensi yang diharapkan pada suatu mata pelajaran (Kementerian Pendidikan dan Kebudayaan, 2021). Penilaian (asesmen) hasil belajar merupakan langkah yang dilakukan untuk mengukur hasil belajar peserta didik (Wilson, 2018). Penilaian hasil belajar oleh pendidik bertujuan untuk memantau dan mengevaluasi proses, kemajuan belajar, perbaikan hasil belajar peserta didik secara berkesinambungan, serta digunakan pemerintah untuk mengambil kebijakan dalam pendidikan (Permendikbud, 2014). Pada skala internasional, instrumen penilaian (asesmen) yang digunakan adalah PISA (Programme for International Student Assessment) dan TIMSS (Trend In International Mathematics And Science Study). Berdasarkan data OECD (2018), peringkat nilai PISA Indonesia tahun 2018 dalam tiga aspek yang dinilai yaitu membaca (peringkat 72 dari 77 negara), matematika (peringkat 72 dari 78 negara), dan sains (peringkat 70 dari 78 negara). Dalam 10-15 tahun terakhir, nilai Indonesia cenderung stagnan. Sementara, nilai TIMSS Indonesia yang dilakukan pada peserta didik kelas 4 tahun 2015 berada pada peringkat ke 44 dari 49 negara pada aspek matematika dan peringkat ke 46 dari 49 negara pada aspek sains (Hadi \& Novaliyosi, 2019).

Hasil penelitian sebelumnya menunjukkan bahwasanya untuk pengetahuan tentang instrumen AKM yang digunakan untuk mengukur kemampuan kognitif peserta didik hanya $28 \%$ guru yang memilih jawaban benar dan tepat (Novita et al., 2021). (Deni Ainur Rokhim, Binti Nuriyati Rahayu, Laila Nur Alfiah,Ristiwi Peni, Bambang Wahyudi,Asnan Wahyudi \& Widarti, 2021) memperoleh hasil penelitian yang menyatakan bahwasanya 15 responden menjawab salah dan 29 responden menjawab benar mengenai kemampuan yang akan diukur dalam Asesmen Kompetensi Minimum (AKM) meliputi literasi membaca dan numerasi. Selain itu diperoleh hasil penelitian yang juga menyatakan 12 responden belum melakukan persiapan menghadapi Asesmen Kompetensi Minimum (AKM) dan 32 responden telah melakukan persiapan menghadapi Asesmen Kompetensi Minimum (AKM).

Berdasarkan latar belakang dapat diketahui bahwasanya masih terdapat guru yang belum memahami mengenai asesmen kompetensi minimum yang akan diselenggarakan oleh kemendikbud tahun 2021 sedangkan guru memiliki peran penting dalam Asesmen Kompetensi Minimum (AKM). Guru sebagai salah satu pilar sistem pendidikan memegang peran dan tanggung jawab yang besar atas efektivitas pelaksanaan AKM. Guna mencapai tujuan ini, maka guru harus memiliki pengetahuan dan kompetensi yang memadahi dalam kaitannya dengan konsep maupun implementasi Asesmen Kompetensi Minimum (M. Anas, Mochamad Muchson, Sugiono, 2021). Oleh karena itu peneliti tertarik untuk melakukan penelitian analisis pemahaman guru Sekolah Menengah Pertama (SMP) dalam memahami Asesmen Kompetensi Minimum (AKM) untuk mengetahui apakah guru mengetahui komponen apa-apa saja dari literasi membaca dan numerasi yang akan diukur dalam asesmen kompetensi minimum, berapa banyak soal AKM nasional yang akan dikerjakan untuk murid SMP, tujuan asesmen kompetensi minimum, dan pengetahuan guru mengenai contoh-contoh soal asesmen kompetensi minimum, kompetensi apa yang diukur pada asesmen kompetensi minimum. 
1553 Analisis Pemahaman Guru Sekolah Menengah Pertama (SMP) Mengenai Asesmen Kompetensi Minimum (AKM) - Aifah Fauzaih, Enur Fitiriani Dewi Sobari, Babang Robandi

DOI: https://doi.org/10.31004/edukatif.v3i4.608

\section{METODE PENELITIAN}

Penelitian ini menggunakan metode survei dengan jenis penelitian kuantitatif deskriptif. Langkah penelitian survei yang dilakukan dalam penelitian ini yaitu: 1) merumuskan masalah dan menentukan tujuan survei; 2) memilih teknik pengumpulan data; 3) membuat instrumen; 4) menyebarkan instrumen; 5) analisis data. Instrumen yang digunakan untuk mengumpulkan data adalah angket menggunakan google form. pengumpulan data penelitian menggunakan instrumen berupa angket yang berisi beberapa pertanyaan untuk menguji pemahaman guru sekolah menengah pertama mengenai Asesmen Kompetensi Minimum (AKM). Tenik pengambilan sampel dalam penelitian menggunakan teknik purposive sampling. Sehingga dipilih sampel dalam penelitian yaitu 8 orang guru SMP yang mengajar di beberbagai daerah. Prosedur dalam penelitian ini sebagai berikut: 1) Merancang instrumen penelitian berupa angket terkait pemahaman guru sekolah menengah pertama mengenai Asesmen Kompetensi Minimum (AKM); 2) validasi angket oleh rekan sejawat; 3) Melakukan revisi instrumen; 4) penentuan sampel; 5) Melakukan penyebaran angket; 6) pengambilan data; 7) melakukan analisis data secara deskriptif. Pengumpulan data penelitian menggunakan instrumen berupa angket pemahaman guru Sekolah Menengah Pertama (SMP) mengenai Asesmen Kompetensi Minimum (AKM) yaitu: 1) pemahaman guru mengenai apakah guru mengetahui apa itu Asesmen Kompetensi Minimum (AKM); 2) pemahaman guru mengenai komponen-kompenen dari literasi membaca dan numerasi; 3) pemahaman guru mengenai banyak soal Asesemen Kompetensi Minimum nasional yang untuk murid SMP; 4) pemahaman guru mengenai komponen yang diukur pada Asesemen Kompetensi Minumum 5) Pemahaman guru mengenai tujuan asesmen kompetensi minimum; dan 6) pemahaman guru mengenai contoh-contoh soal Asesmen Kompetensi Minimum (AKM).

\section{HASIL DAN PEMBAHASAN PENELITIAN}

Hasil penelitian ini mencoba memaparkan pemahaman guru mengenai Asesmen Kompetensi Minimum (AKM) yang dikumpulkan berdasarkan angket yang hanya fokus menanyakan guru mengenai pemahamannya dalam bentuk jawaban ya atau tidak serta pernah atau belum pernah. Dengan penyebaran angket menggunakan google form kepada 8 orang guru yang mengajar di sekolah yang berada di daerah Jambi, Bandung, dan bogor. Berdasarkan pengumpulan data yang dilakukan melalui penyebaran angket terkait pemahaman guru sekolah menengah pertama mengenai kompetensi minimum (AKM). Pada pertanyaan angket pertama diperoleh $100 \%$ yang mengetahui apa itu asemen kompetensi minimum (gambar 1). Seperti yang telah disampaikan oleh (Kementerian Pendidikan dan Kebudayaan, 2021) bahwa Asesmen kompetensi minimum merupakan salah satu bagian dari asesmen nasional yang merupakan salah satu bentuk program evaluasi pendidikan oleh Kemendikbud untuk memberikan gambaran tingkatan kompetensi murid di setiap satuan pendidikan pada literasi membaca dan numerasi. Hasil asesmen kompetensi minimum dapat dijadikan pedoman untuk melakukan evaluasi dalam proses pembelajaran. satuan pendidikan diharapkan mampu merefleksikan hasil Asesmen Kompetensi Minimum (AKM) sehingga guru-guru menerapkan teaching at the right level sekaligus fokus membangun kompetensi serta karakter peserta didik. Serta diharapkan untuk ditindak lanjuti manajemen satuan pendidikan untuk menyusun dan melaksanakan program-program satuan pendidikan untuk mendorong terciptanya iklim belajar yang kondusif serta positif 
1554 Analisis Pemahaman Guru Sekolah Menengah Pertama (SMP) Mengenai Asesmen Kompetensi Minimum (AKM) - Aifah Fauzaih, Enur Fitiriani Dewi Sobari, Babang Robandi

DOI: https://doi.org/10.31004/edukatif.v3i4.608

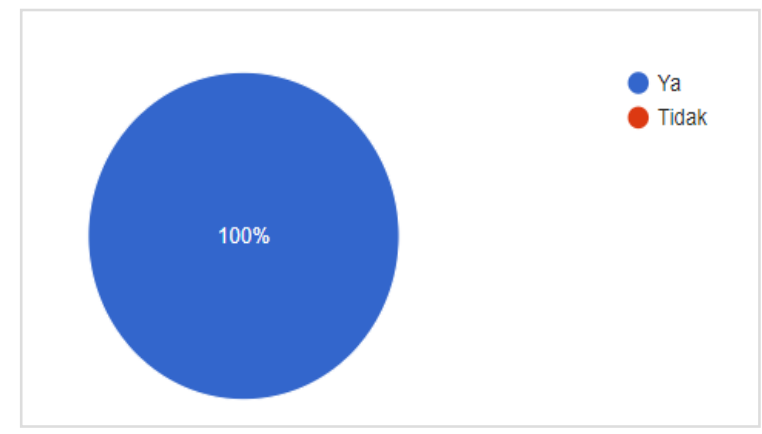

\section{Gambar 1. Guru mengetahui apa itu AKM}

Untuk angket pertanyaan kedua yaitu mengenai apa-apa sajakah komponen dari literasi membaca dan numerasi yang akan diukur dalam asesmen kompetensi minimum yang akan diselenggarakan kemendikbud telah diperoleh bahwasanya sebanyak $87,5 \%$ guru mengetahui komponen apa-apa saja dari literasi membaca dan numerasi yang akan diukur dalam asesmen kompetensi minimum dan sebanyak $12,5 \%$ guru yang tidak mengetahui (gambar 2). Berdasarkan hasil jawaban angket pertanyaan kedua dapat diketahui bahwasanya masih ada guru yang belum mengetahui komponen apa-apa saja dari literasi membaca dan numerasi yang akan diukur dalam Asesmen Kompetensi Minimum (AKM). Hal ini menunjukkan bahwasanya perlu dilakukan kegiatan sosialisasi mengenai Asesemen Kompetensi Minimum (AKM) oleh pihak sekolah kepada guru. Pemahaman guru untuk pertanyaan kedua ini tidak sesuai seperti yang disampaikan oleh Kementerian Pendidikan dan Kebudayaan (2021) yaitu: 1) konten; 2) proses kognitif, serta konteks. Aspek konten pada bagian literasi membaca yaitu berupa teks informasi dan sastra. Sedangkan bagian numerasi untuk komponen konten pada bagian aspek numersai yaitu mengenai aljabar, bilangan geometri, pengukuran, data dan ketidakpastian. Pada komponen aspek proses kognitif untuk literasi membaca yaitu menemukan, interpretasi, evaluasi, dan refleksi informasi. Sedangkan bagian numerasi untuk komponen proses kognitif yaitu berupa pemahaman, penerapan, dan penalaran. Untuk komponen aspek konteks untuk literasi membaca yaitu personal, sosial, budaya, saintifik. Sedangkan bagian numerasi untuk komponen konteks yaitu personal, sosial budaya, dan saintifik.

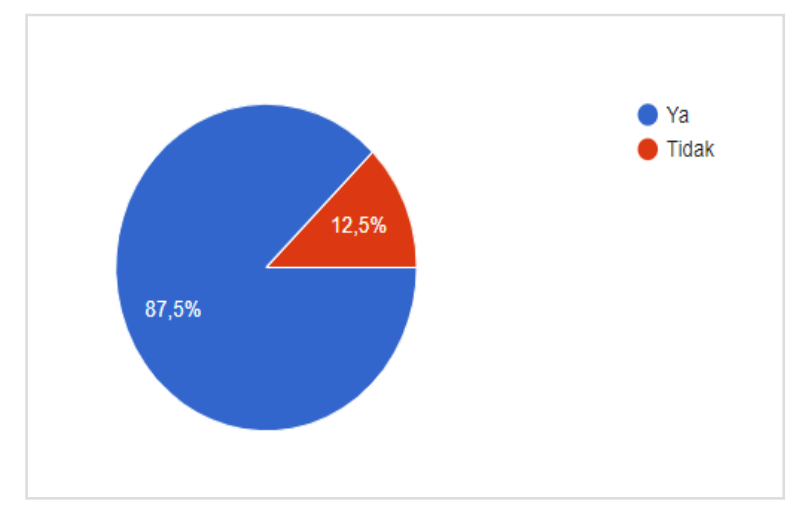

\section{Gambar 2. Pemahaman guru mengenai komponen dari literasi membaca dan numerasi}

Untuk angket pertanyaan ketiga mengenai pemahaman guru apakah hanya literasi membaca dan numerasi yang diukur pada soal-soal Asesmen Kompetensi Minimum (AKM), diperoleh 62,5\% yang menjawab salah yaitu tidak hanya literasi membaca dan numerasi yang diukur pada soal-soal AKM dan 37,5\% yang menjawab benar (gambar 3). Hal Ini tidak sesuai dengan apa yang telah disampaikan (Kementerian Pendidikan dan Kebudayaan, 2021) bahwasanya Asesemen Kompetensi Minimum (AKM) hanya akan mengukur literasi membaca dan numerasi karena merupakan kemampuan atau kompetensi mendasar yang dibutuhkan oleh semua murid. Serta pengertian minimum menunjukkan literasi membaca 
1555 Analisis Pemahaman Guru Sekolah Menengah Pertama (SMP) Mengenai Asesmen Kompetensi Minimum (AKM) - Aifah Fauzaih, Enur Fitiriani Dewi Sobari, Babang Robandi

DOI: https://doi.org/10.31004/edukatif.v3i4.608

dan numerasi yang merupakan kompetensi yang setidak-tidaknya harus harus dimiliki untuk seseorang yang dapat berfungsi secara produktif dalam kehidupan. Dari hasil penelitian dapat dilihat bahwasanya kurangnya pemahaman guru mengenai kompenen yang diukur pada Asesemen Kompetensi Minumum (AKM). Hal Sesuai dengan dengan hasil penelitian (Deni Ainur Rokhim, Binti Nuriyati Rahayu, Laila Nur Alfiah,Ristiwi Peni, Bambang Wahyudi,Asnan Wahyudi \& Widarti, 2021), yang menyatakan bahwasanya sebagian besar calon guru tidak mengetahui komponen yang diukur dalam AKM karena 15 responden menjawab salah dan 29 responden menjawab benar mengenai kemampuan yang akan diukur dalam Asesmen Kompetensi Minimum (AKM) meliputi literasi membaca dan numerasi.

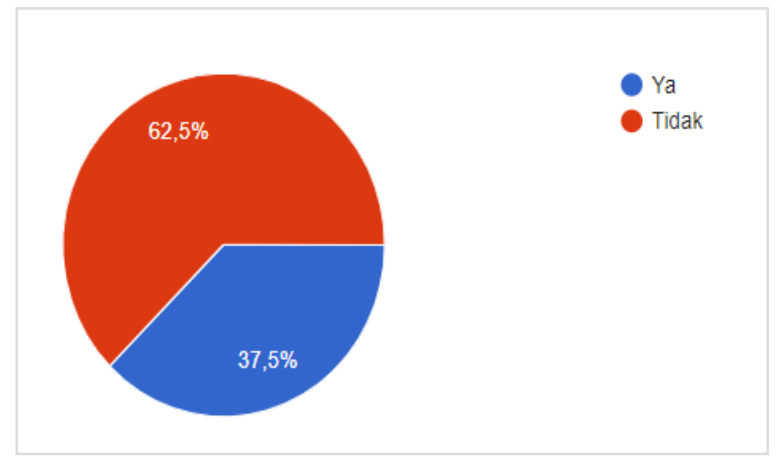

\section{Gambar 3. Pemahaman guru mengenai kemampuan yang diuji dalam AKM}

Pada angket pertanyaan keempat mengenai banyaknya soal AKM nasional yang akan dikerjakan untuk murid SMP diperoleh sebanyak 25\% guru yang memberikan jawaban benar yaitu 36 soal dan 75\% guru yang memberikan jawaban salah yaitu 30 soal (gambar 4). Pemahaman guru untuk pertanyaan keempat ini tidak sesuai seperti yang disampaikan oleh (Kementerian Pendidikan dan Kebudayaan, 2021) bahwasanya untuk tingkat sekolah menengah pertama (SMP) akan mengerjakan soal sebanyak 36 soal untuk masing-masing untuk kemampuan literasi membaca dan numerasi. Berdasarkan hasil jawaban angket pertanyaan keempat dapat diketahui bahwasanya kurangnya pemahaman guru mengenai banyak soal Asesemen Kompetensi Minimum (AKM) yang akan diujikan untuk murid SMP. Kurangnya pemahaman guru mengenai banyaknya soal Asesmen Kompetensi Minimum (AKM) bisa disebabkan oleh kurangnya kegiatan sosialisasi dan pelatihan kepada guru mengenai soal-soal AKM. Berdasarkan hasil penelitian (M. Anas, Mochamad Muchson, Sugiono, 2021) memberikan pelatihan mengenai Asesmen Kompetensi Minimum (AKM) pada guru mampu memberikan hasil positif berupa peningkatan kompetensi yang harus dimiliki oleh guru. Peningkatan kompetensi guru ini meliputi aspek pengetahuan mengenai Asesmen Kompetensi Minimum (AKM).

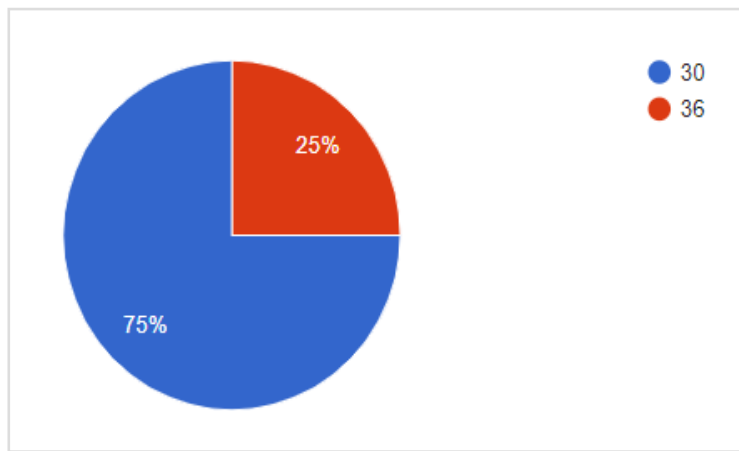

\section{Gambar 4. Pemahaman guru mengenai banyak soal AKM}

Pada angket pertanyaan kelima mengenai pemahaman guru apakah soal-soal Asesmen Kompetensi Minimum (AKM) nasional bertujuan untuk mengukur tingkat kompetensi individu peserta didik, diperoleh 
1556 Analisis Pemahaman Guru Sekolah Menengah Pertama (SMP) Mengenai Asesmen Kompetensi Minimum (AKM) - Aifah Fauzaih, Enur Fitiriani Dewi Sobari, Babang Robandi

DOI: https://doi.org/10.31004/edukatif.v3i4.608

sebanyak 75\% memberikan jawaban ya dan 25\% jawaban tidak (gambar 5). Dari hasil penelitian untuk angket pertanyaan kelima dapat diketahui bahwasanya lebih tinggi presentase jawaban guru yang salah. Dapat diketahui bahwa masih rendahnya pemahaman guru mengenai tujuan Asesmen Kompetensi Minimum (AKM). Pemahaman guru untuk pertanyaan kelima ini tidak sesuai seperti yang disampaikan oleh (Kementerian Pendidikan dan Kebudayaan, 2021) bahwa Asesmen Kompetensi Minimum (AKM) nasional tidak bertujuan untuk mengukur kompetensi ditingkat peserta didik atau murid akan tetapi bertujuan untuk melaporkan pada level satuan pendidikan dan mengevaluasi dan memetakan sistem pendidikan berupa input, proses, dan hasil. Satuan Pendidikan diharapkan menjadikan hasil Asesmen Kompetensi Nasional (AKM) sebagai alat refleksi untuk memperbaiki kualitas pembelajaran dan iklim satuan pendidikan.

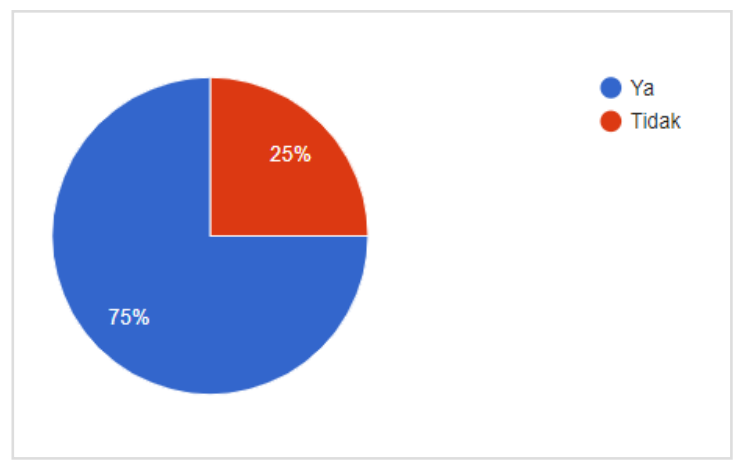

\section{Gambar 5. Pemahaman guru mengenai tujuan AKM}

Pada angket pertanyaan keenam mengenai pernah atau tidak guru mencoba mengerjakan contohcontoh soal Asesmen Kompetensi Nasional (AKM), diperoleh 62,5\% yang memberikan jawaban belum pernah dan 37,5\% memberikan jawaban pernah (gambar 6). Dari hasil penelitian untuk angket pertanyaan keenam dapat diketahui bahwasanya lebih tinggi persentase guru yang belum pernah mencoba mengerjakan contoh-contoh soal Asesmen Kompetensi Minimum (AKM). Guru sangat berperan penting dalam mempersiapkan peserta didik untuk memiliki kemampuan literasi membaca dan numerasi. Oleh karena itu sangat dituntut guru untuk bisa memahami contoh soal-soal Asesmen Kompetensi Minimum (AKM) agar mampu membimbing peserta didik dalam memahami contoh-contoh soal AKM. Sebagaimana yang telah disampaikan oleh (Kementerian Pendidikan dan Kebudayaan, 2021) bahwa satuan pendidikan terutama guru diharapkan aktif mengikuti simulasi sebagai upaya menyiapkan murid menghadapi AKM. Pihak sekolah diharapkan bisa memberikan pelatihan kepada guru untuk mecoba memahami dan mengerjakan contohcontoh soal yang telah disediakan oleh Pusmenjar pada laman https://pusmenjar.kemendikbud.go.id/akm untuk membantu guru dalam mengatasi rasa kaget dan bingung mengenai tuntutan penalaran yang tinggi dalam menyelesaikan contoh-contoh soal Asesmen Kompetensi Minimum (AKM). Seperti yang telah disampaikan dalam penelitian (M. Anas, Mochamad Muchson, Sugiono, 2021) bahwasanya secara terbatas AKM ini telah diujicobakan pada guru. Sesaat setelah menghadapi AKM, banyak guru yang kaget sekaligus menyuarakan pemikiran tentang tes soal AKM. Rasanya wajar saja. Ini tak lepas bahwa soal-soal yang disodorkan terasa sangat holistik dan penuh kontemplatif. Butuh penalaran kelas tinggi dalam menyelesaikan soal-soal tersebut. Oleh karena itu perlunya kegiatan pelatihan sebagai upaya meningkatkan kompetensi guru untuk soal-soal AKM. 
1557 Analisis Pemahaman Guru Sekolah Menengah Pertama (SMP) Mengenai Asesmen Kompetensi Minimum (AKM) - Aifah Fauzaih, Enur Fitiriani Dewi Sobari, Babang Robandi

DOI: https://doi.org/10.31004/edukatif.v3i4.608

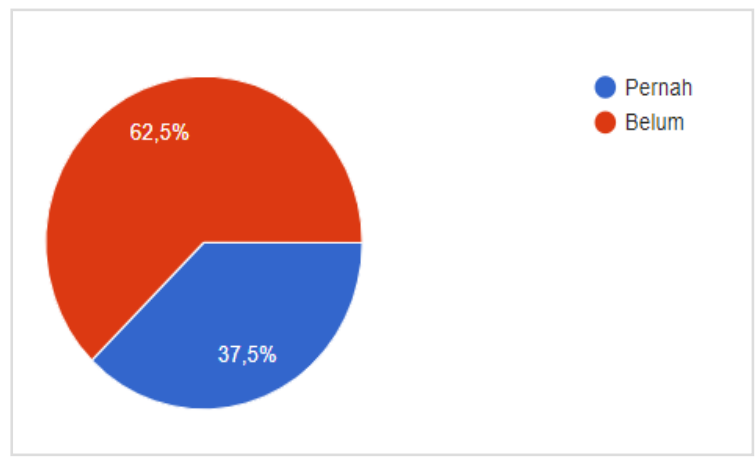

Gambar 6. Guru mencoba mengerjakan soal AKM

\section{KESIMPULAN}

Asesmen kompetensi minimum (AKM) merupakan salah satu bagian dari asesmen nasional yang merupakan salah satu bentuk program evaluasi pendidikan oleh Kemendikbud untuk memberikan gambaran tingkatan kompetensi murid di setiap satuan pendidikan pada literasi membaca dan numerasi. Hasil asesmen kompetensi minimum dapat dijadikan pedoman untuk melakukan evaluasi dalam proses pembelajaran. Dapat disimpulkan dari hasil penelitian $100 \%$ guru mengetahui apa itu asesmen kompetensi minimum, 87,5\% guru mengetahui komponen apa-apa saja dari literasi membaca dan numerasi yang akan diukur dalam asesmen kompetensi minimum dan sebanyak $12,5 \%$ guru yang tidak mengetahui. Pemahaman guru mengenai apakah hanya literasi membaca dan numerasi yang diukur pada soal-soal asesmen kompetensi minimum (AKM), $62,5 \%$ yang menyatakan tidak hanya literasi membaca dan numerasi yang diukur pada soal-soal asesmen kompetensi yang menjawab dan 37,5\% ya, 25\% guru yang memberikan jawaban bahwa untuk SMP jumlah soal asesemen kompetensi minimum untuk masing-masing literasi membaca dan numerasi yaitu 36 soal dan 75\% guru yang memberikan jawaban yaitu 30 soal, sebanyak $75 \%$ guru memberikan jawaban bahwa kompetensi minimum nasional bertujuan untuk mengukur tingkat kompetensi individu peserta didik dan $25 \%$ jawaban tidak. $62,5 \%$ yang memberikan jawaban belum pernah mencoba mengerjakan contoh-contoh soal asesmen kompetensi minimum dan 37,5\% memberikan jawaban pernah. Hal Ini menunjukkan bahwasanya masih rendahnya pemahaman guru mengenai Asesmen Kompetensi Minimum (AKM). Artinya asesmen kompetensi minimum perlu disosialisasikan lebih terhadap SDM yang ada terutama guru agar bisa mengimplementasikan memberikan contoh-contoh soal sejenis sebagai upaya peningkatan kualitas hasil belajar siswa.

\section{DAFTAR PUSTAKA}

Adom, D., Mensah, J. A., \& Dake, D. A. (2020). Test, measurement, and evaluation: Understanding and use of the concepts in education. International Journal of Evaluation and Research in Education, 9(1), 109119. https://doi.org/10.11591/ijere.v9i1.20457

Ayang Sari, Syahnan Daulay, Yola Yuliani Putri, P. E. (2020). Penghapusan Ujian Nasional Tahun 2021 Dalam Perspektif Guru SMA Di Kota Tebing Tinggi. Seminar Nasional PBSI-III, 213-220.

Baird, J. A., Andrich, D., Hopfenbeck, T. N., \& Stobart, G. (2017). Assessment and learning: fields apart? Assessment in Education: Principles, Policy and Practice, 24(3), 317-350. https://doi.org/10.1080/0969594X.2017.1319337

Brown, G. T. L. (2019). Is Assessment for Learning Really Assessment? Frontiers in Education, 4(June), 1-7. https://doi.org/10.3389/feduc.2019.00064

Deni Ainur Rokhim, Binti Nuriyati Rahayu, Laila Nur Alfiah,Ristiwi Peni, Bambang Wahyudi,Asnan Wahyudi, \& Widarti, H. R. (2021). Analisis Kesiapan Peserta Didik Dan Guru Pada Asesmen Nasional 
1558 Analisis Pemahaman Guru Sekolah Menengah Pertama (SMP) Mengenai Asesmen Kompetensi Minimum (AKM) - Aifah Fauzaih, Enur Fitiriani Dewi Sobari, Babang Robandi

DOI: https://doi.org/10.31004/edukatif.v3i4.608

(Asesmen Kompetensi Minimum , Survey Karakter, Dan Survey Lingkungan Belajar). Jurnal Administrasi Dan Manajemen Pendidikan, 4, 61-71.

Hadi, S., \& Novaliyosi. (2019). TIMSS Indonesia (Trends in International Mathematics and Science Study). Prosiding Seminar Nasional \& Call For Papers Program Studi Magister Pendidikan Matematika Universitas Siliwangi, 562-569.

Kementerian Pendidikan dan Kebudayaan. (2021). Asesmen Nasional, Lembar Tanya Jawab. Kementerian Pendidikan Dan Kebudayaan, 1-32.

https://hasilun.puspendik.kemdikbud.go.id/akm/file_akm_202101_1.pdf

M. Anas, Mochamad Muchson, Sugiono, R. F. (2021). Rengganis Jurnal Pengabdian Masyarakat Pengembangan kemampuan guru ekonomi di Kediri melalui kegiatan pelatihan asesmen kompetensi minimum ( AKM ). 1, 48-57.

Mendikbud. (2020). AKM dan Implikasinya pada Pembelajaran. Pusat Asesmen Dan Pembelajaran Badan Penelitian Dan Pengembangan Dan Perbukuan Kementerian Pendidikan Dan Kebudayaan, 1-37.

Novita, N., Mellyzar, M., \& Herizal, H. (2021). Asesmen Nasional (AN): Pengetahuan dan Persepsi Calon Guru. JISIP (Jurnal Ilmu Sosial Dan Pendidikan), 5(1), 72-79.

http://ejournal.mandalanursa.org/index.php/JISIP/index

OECD. (2015). Pisa 2015. Pisa 2015.

Pellegrino, J. W. (2014). Assessment as a positive influence on 21 st century teaching and learning: A systems approach to progress. Psicologia Educativa, 20(2), 65-77. https://doi.org/10.1016/j.pse.2014.11.002

Permendikbud. (2014). Permendikbud nomor 104 tahun 2014 Tentang Penilaian Hasil Belajar oleh Pendidik pada Pendidikan Dasar dan Pendidikan Menengah. Kementrian Pendidikan Dan Kebudayaan RI, 1-8. https://luk.staff.ugm.ac.id/atur/bsnp/Permendikbud104-2014PenilaianHasilBelajar.pdf

Wiliam, D. (2011). What is assessment for learning? Studies in Educational Evaluation, 37(1), 3-14. https://doi.org/10.1016/j.stueduc.2011.03.001

Wilson, M. (2018). Making Measurement Important for Education: The Crucial Role of Classroom Assessment. Educational Measurement: Issues and Practice, 37(1), 5-20.

https://doi.org/10.1111/emip.12188 